\title{
POPULATION VULNERABILITY EVALUATION AGAINST LONG-TERM FLOODS IMPACTS
}

\author{
Pavel ŠENOVSKÝ ${ }^{1}$
}

Research article

\begin{tabular}{|c|c|}
\hline Abstract: & $\begin{array}{l}\text { The evaluation of the location vulnerability is one of the most complex problems we } \\
\text { are facing when trying to protect the population safety. One of the areas of vulnerability } \\
\text { evaluation, which has been mostly ignored in the past, is the assessment of the area from } \\
\text { the point of view of the social structure of the population living there. For such purposes, } \\
\text { SFVI (Social Flood Vulnerability Index) has been developed in Great Britain, capable of } \\
\text { evaluation "tangible" damages caused by floods. This article evaluates the possibilities of } \\
\text { using this index in the Czech Republic. }\end{array}$ \\
\hline Keywords: & Flood, vulnerability, SFVI, Towsend's index. \\
\hline
\end{tabular}

\section{Introduction}

Evaluation of the location vulnerability is one of the most complex problems we are facing when trying to protect the population. Vulnerability of the chosen area is studied usually in the context of the expected impacts of the disaster of projected magnitude -in our case the flood. For example, DeBrujin (2005) specified the following possible impacts for this type of disaster (see Tab. 1).

Tab. 1 Categories of the negative impacts of floods

\begin{tabular}{|c|c|c|c|}
\hline \multicolumn{2}{|c|}{ Category } & Tangible & Intangible \\
\hline \multirow{2}{*}{ 莺 } & 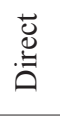 & $\begin{array}{c}\text { Capital loss } \\
\text { (property, vehicles, } \\
\text { crop, ...) }\end{array}$ & $\begin{array}{l}\text { Causalities, } \\
\text { ecosystems, } \\
\text { contamination }\end{array}$ \\
\hline & 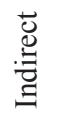 & $\begin{array}{l}\text { Loss in the } \\
\text { production, loss of } \\
\text { income }\end{array}$ & $\begin{array}{l}\text { Social turbulences, } \\
\text { mental stress }\end{array}$ \\
\hline 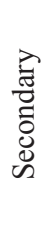 & & $\begin{array}{l}\text { Loss in the } \\
\text { production in } \\
\text { regions not } \\
\text { impacted by floods, } \\
\text { unemployment, } \\
\text { migration, inflation }\end{array}$ & $\begin{array}{l}\text { Emotional } \\
\text { perception of the } \\
\text { damage, damages } \\
\text { to ecosystems } \\
\text { outside flooded area }\end{array}$ \\
\hline 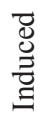 & & Cost of relief effort & $\begin{array}{l}\text { Stress from } \\
\text { evacuation }\end{array}$ \\
\hline
\end{tabular}

While tangible impacts are successfully incorporated into the risk management of the region (i.e. using insurance, emergency planning, etc.). „Intangible“ impacts are problematic - their impact is supposedly large, but also very hard to estimate.

\section{Materials and methods}

\section{Evaluation of intangible losses}

As intangible, we consider especially the longterm impacts of the emergencies on human health, both physical and mental. Losses of the items of personal value, of collectibles, but also of pets, which themselves do not have large monetary value but are priceless for its owner, all these contribute to intangible losses.

Tapsell et al. (2002) published a series of studies on floods in north-eastern England between June $3^{\text {rd }}$ and $5^{\text {th }}, 2002$, Milojevic et al. (2011) analyzed 319 floods in England in 1994-2005.

Milojevic (Milojevic et al., 2011) focused his study on the impact of flood as a major event in human life with health impact leading to shortening the life of those who have suffered the flood. Milojevic compares numbers of deceased in the year preceeding the flood and the year after the flood and gets consistent results over the dataset. In the year after the flood there was $10 \%$ average decrease of deceased. In the control regions with no flood at that time, there was only $1 \%$ decrease on average. That is a counterintuitive result. The structure of the cause of death is as we would expect - there was a large increase of those who died as a result of infections of various kinds.

Tapsell et al. were interested in several focus groups of respondents from different recently flooded areas. The data for the research have been collected using face to face interviews and consequently analyzed to create the profile of the respondent illustrating his/her opinions and feelings on the floods before, during and after they happened.

VŠB - Technical University of Ostrava, Faculty of Safety Engineering, Ostrava, Czech Republic, pavel.senovsky@vsb.cz 
The research itself has been focused on social-health impacts of the floods.

Graphically we could visualize the framework into which Tapsell localized his research (Tapsell et al., 2002) as illustrated on Fig. 1 (adapted from (Tapsell et al., 2002).

\section{Before the flood}

- Risk of flood perceived as insignificant.

- Lack of preparedness to deal with the aftermath of flood.

- Majority of respondents think that the Environmental Agency should have better informed about flood ris.

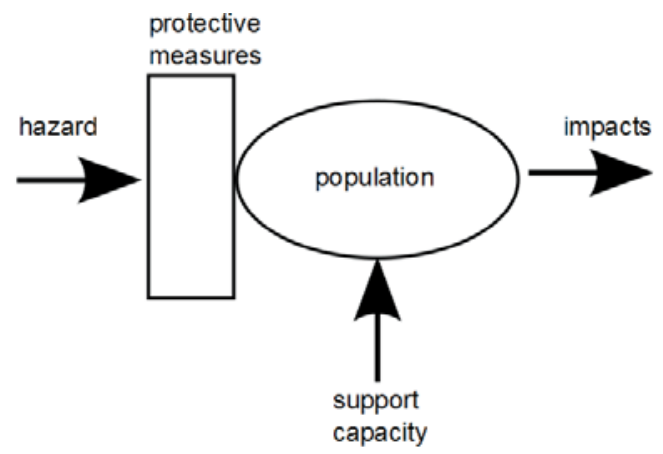

Fig. 1 Framework of Tapsell's research

\section{During the flood}

- Shock from the speed and strength of natural forces.

- Endangerment of lives.

- Most people were informally warned of the danger, which allowed them to save some personal belongings.

- Some assistances of emergency services, but the large portion of population had to help itself.

- Critics of the local government.

\section{After the flood}

- The extent of damage on the property sinks in, with especially painful damage on the personal belonging.

- Evacuation was perceived as stress factor, more so as usually there were only limited lodging capacities on place.

- Residents who chose not to evacuate had to deal with changed life conditions.

- Problems with getting time off to deal with the flood damage from employers.

- Volunteer work has been rated positively.

- Construction companies criticized for its slowness, low work quality, unreliability, and unpleasant stance.
The floods had different impacts on people. The impacts are more severe for females than males, seniors than young people, partial families than whole families, poor rather than wealthy, chronically ill than healthy.

For the evaluation of vulnerability of the area from the point of view of such ,intangible“ losses, Tapsell proposes SFVI index (Social Flood Vulnerability Index). Data for the index must be sufficiently detailed in the sense of the area they cover. The reason for this is that the floods are usually strictly localized in space, so the data should cover the areas in danger. Original SFVI index has been developed to the level of the postcode.

For the pilot phase of the evaluation, Tapsell used census data from 1991 gathered by MIMAS (Manchester Information and Associated Services) (CDU, 2011).

SFVI uses as ist base the Towsend's index, which provides information to measure the deprivation and disadvantage of the residents of the area. Tapsell added several variables to the Towsend's index to create SFVI.

\section{Towsend's index - variables}

1)Unemployment rate - unemployment rate of residents ageed $16+$ as the percentage of economically active residents.

2)Overcrowding - number of the households with more than one person per room as the percentage of all households in the area.

3)Households without the car - as the percentage of all households in the area.

4)Households not owing their lodging - number of households which do not own house they live in.

\section{Variables of SFVI index (as percentage of all residents in the area)}

1)chronically ill,

2)partial families,

3)seniors aged $75+$.

The SFVI index is constructed in such a way that we apply transformation functions (see Tab. 2) to all index's variables first and then we sum them up. The Towsend's index variables are also multiplied by 0,25 to lower the relative importance of Townsend' $\mathrm{s}$ index to $25 \%$ of its original value, so that it does not outbalance the remainder of SFVI. 
Tab. 2 Transformation functions of SFVI index

\begin{tabular}{|l|c|}
\hline Index variable & Transformation function \\
\hline Partial families & $\ln (\mathrm{x}+1)$ \\
\hline Seniors aged 75+ & $\ln (\mathrm{x}+1)$ \\
\hline Chronically ill & $\sqrt{x}$ \\
\hline $\begin{array}{l}\text { Households not owing } \\
\text { their lodging }\end{array}$ & $\sqrt{x}$ \\
\hline Unemployment & $\ln (\mathrm{x}+1)$ \\
\hline Households without car & $\sqrt{x}$ \\
\hline Overcrowding & $\ln (\mathrm{x}+1)$ \\
\hline
\end{tabular}

In 2004, DEFRA (Department for Environment Food and Rural Affairs) published an extensive study (DEFRA, 2004) of the intangible impacts of floods on residents. DEFRA has undertaken three rounds questionnaire (two pilot studies and a main study). DEFRA focused on resident who were affected or endangered by floods. The study has been carried out in the areas of Great Britain, which were affected by floods between the years 1999 to 2001 . The questionnaire has been sent to 1500 respondents (with $75 \%$ return rate).

DEFRA study proved that floods do affect human health but the impact itself is not so strong and does not last that long as one would expected (most impacts wear out during the first six months after the flood). Interesting results of the study regarding protective measures and their implementation are presented in tab. 3 .

Tab. 3 Affected vs. endangered (by flood) residents implementation of protective measures

\begin{tabular}{|l|c|c|}
\hline \multicolumn{1}{|c|}{ Measure } & Affected & Endangered \\
\hline Insurance against flooding & $60 \%$ & $44 \%$ \\
\hline $\begin{array}{l}\text { Monitoring of floods } \\
\text { warnings }\end{array}$ & $51 \%$ & $48 \%$ \\
\hline $\begin{array}{l}\text { Moving of valuable } \\
\text { properties to upper floors }\end{array}$ & $36 \%$ & $18 \%$ \\
\hline Sand bags in the property & $25 \%$ & $15 \%$ \\
\hline Maintenance of drainage & $22 \%$ & $21 \%$ \\
\hline
\end{tabular}

Not surprisingly, the residents who have firsthand experience with the floods were more willing to invest into protective measures than those who live in endangered areas but were not flooded yet.

Project MICRODIS came (Jakubicka et al., 2011 ) to the same conclusion in its study. The project MICRODIS mapped the impacts of floods on the health of population in Germany, France and Italy.

\section{Results}

\section{Application of SFVI index in the Czech Republic}

Generally speaking, the usage of SFVI index in the Czech Republic is possible but the indexation of the regions will be more complicated in the Czech Republic due to the different way of necessary data gathering. Let's look on index variables and search for the data sources we can use.

\section{Towsend's index}

Unemployment rate - it is possible to use Work bureau statistic data. This information can be gathered by the bureau from the form called "Request for enlistment into the evidence of applicants for work" (MPSV, 2011). The form distinguishes domicile (as place of permanent residence) and corresponding addresses. Unfortunately, both addresses can point to location where the applicant does not live - which makes this information unreliable to use in index construction.

Much more reliable information are provided by census data that keep track of the economic activity of the population in places where they actually live. Unfortunately, census data have their own flaws. The census is performed once in ten years, so the data at the end of decade may not accurately describe the reality. Another problem is that not every time it is possible to gather all data, for example only in Olomouc ${ }^{1}$ (ČSÚ, 2003) this information was not determined for 881 residents (out of 102607 ), which is $0,86 \%$.

Regardless of these irregularities, I consider census data a better data source for the construction of the index. This assertion is also supported by the interview (ČSÚ, 2011) with Stanislav Drapal, vice chairman of the Czech statistical bureau, for CRo1 - Radiozurnal. He stated that there are tens of thousands of people in the Czech Republic who have permanent residence at municipal office and that this number does not include people who do not live at their places of permanent residence. Let's also note that similar approach has been chosen by Tapsell (Tapsell et al., 2002) in his pilot study.

Data on overcrowding are also derivable from census data - from the so called lodging form. In this form there are data stating the number of living rooms and the number of people who live in the lodging can be derived from the list of people who live there.

Number of households without car is not possible to derive from census 2011 data, because there is simply not a field to hold this information (as opposed to census 2001 (ČSÚ, 2011b) data, which contains this

City Olomouc has been chosen randomly. 
information). The 2011 form has only the question on the means of transportation to the workplace. The respondent can choose: usage of car - driver. Unfortunately in this way, it is possible to identify only part of the households owning the car. Especially unprivileged households can have car, but for financial reasons can use it only rarely - so they can choose to move to workplace by means of public transport.

It is also possible that this index variable is significant for the Great Britain only, for which the SFVI index has been developed and tested. Tapsell's study (Tapsell et al., 2002) showed that only the minority of respondents has been provided by official help of emergency services (outside of mandatory warning of the danger).

The experience from the Czech Republic from dealing with the floods in the history show clearly that crisis staff are fully prepared to organize even large scale area evacuations. So the households in the Czech Republic may not be so much vulnerable by absence of cars as their British counterparts.

On the other hand, the availability of a car indicates the mobility of work force and the capability of the population to deal with turbulences in economic environment as the aftermath of the floods. Mobility of work force in the Czech Republic is considered low, even taking into account the better mobility of young people as compared to older generations - see the survey of university and secondary school graduates of 2010 (LMC, 2011) compared to the year 2003 (Vojtěch et al., 2003).

Information about owning the housing is again possible to derive from lodging form, the field legal relationship to the lodging.

To summarize things - it is possible to construct original Towsend's index only using census 2001 data. To use newer data we would have to ignore households owning the car variable or replace it by estimations based on additional surveys. It is questionable if such a survey can successfully collect sufficiently detailed data, considering significantly lower return rate (census is mandatory as opposed to other surveys), financial costs and the dimension of the task itself. The questions regarding economical statue, property and such are also considered sensitive $^{2}$, which means that respondents would be less willing to answer such questions.

Removing the variable seems to be the only viable option at present time. Removal of a variable would mean that it would be necessary to change the coefficient used to incorporate Towsend's index into SFVI.

2 This is also one of the reasons to remove this question from Census 2011.
If we explore behavior of transformation functions for the computation of Towsend's index (see Tab. 2), we find that logarithmic function takes the value in interval $<0 ; 5>$ and $\sqrt{x}$ lies in the interval $<0 ; 10>$, see Fig. 2 .
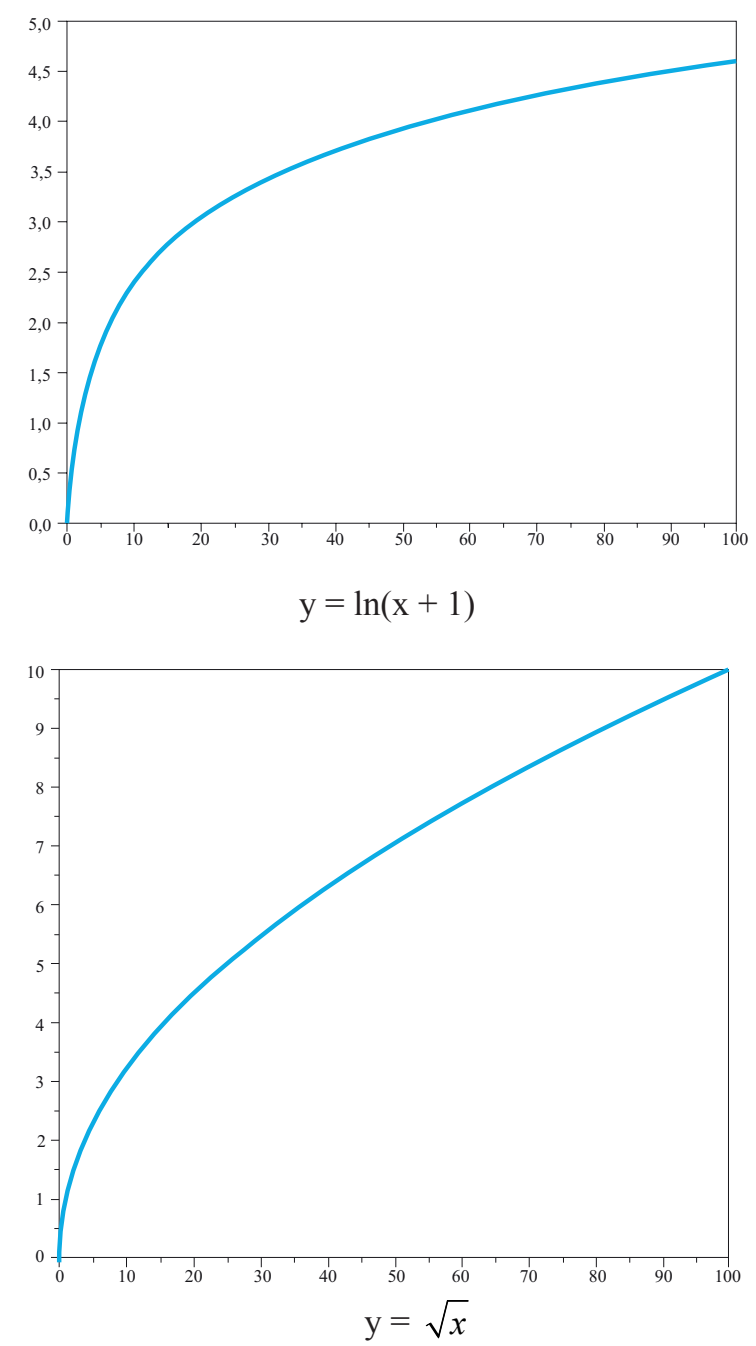

Fig. 2 Graphs of transformation functions of SFVI

That means that Towsend's index in its original form takes values in the interval $<0 ; 30\rangle$. When removing the part of the index regarding households owning the car, the index loses 10 points $(33,3 \%)$ of its value. Modified Towsend's index would take values in the interval of $\langle 0 ; 20\rangle$. To maintain the relative significance of the index as related to SFVI, we would have to increase the integration coefficient up to 0,333 from original 0,25 .

\section{Index SFVI}

The number of senior citizens aged 75+, as well as the number of partial families, can be derived from personal forms of census data. The third variable number of chronically ill in the area - is very hard 
to get in the Czech Republic. SFVI is primarily concerned with the subjective perception of health by respondents, while in the Czech Republic there are lots of indicators focused on determining objective health status of the population, as reported by medical doctors, hospitals, etc. and published by the Institute of health information and statistic, for example (UZIS, 2010).

Form for the census of households (ESRC Census Programme, 2011) in Great Britain contains two questions focused on health. Only a small note: the census forms in Great Britain contain sub-forms focused on the household members.

1)Over the last twelve months, would you say your health has on the whole been:
a. good?
b. fairly good?
c. not good?

2)Do you have any long-term illness, health problem or disability, which limits your daily activities or the work you can do? Answer: yes or no.

The answers to the second question are used by Tapsell (Tapsell et al., 2002) for his SFVI index. Because such data are not available in the Czech Republic, it would be necessary to replace it by similar indicator.

Theoretically it could be possible to gather the number of people with disabilities from associations organizing them. Estimating the number of longterm ill (not hospitalized) would be much harder. Alternatively, it could be feasible to develop a population health indicator based on other indicators, for example function of education or severity of the work, age, living place and lifespan. The usage of such an alternative indicator would require new study and its rigorous verification. Also the difference between the original indicator and the new one would be very hard to estimate.

\section{Index usage}

In case the problems mentioned above could be successfully resolved, the regions could be classified from the point of view of the social vulnerability. Index methods in general are easily applicable using GIS, and the SFVI index, as proved by Tapsell's pilot study, is not different.

The layer of classified territory using SFVI could be combined with other existing layers of floodplains to find vulnerable areas. This information could be used for the long-term planning of area development with the ultimate goal to minimalize the vulnerability.

When dealing with the on-coming flood, the vulnerable areas should be informed as soon as possible, so that its residents have maximum time available to realize protective measures to minimize flood damage on their property.

For such „operative“ evaluation of the endangered zones, it should be possible to use software packages such as FLOREON+ (Unucka et al., 2010). Considering that FLOREON+ is also a GIS application, the SFVI should be easy to incorporate and to find out if the predicted flooding will endanger vulnerable areas or not on the basis of actual flood parameters.

It is also possible to combine the index with other methods covering different parts of safety of the territory, for example from the point of view of the territory development, see Rehak (2010).

\section{Conclusion}

Tapsell's study (Tapsell et al., 2002) proved that it is possible to measure vulnerability of residents against the floods. Unfortunately, the direct application of the proposed SFVI index, capable to measure this vulnerability, into the Czech Republic is not possible due to incompatibility in data gathered in census. While most indicators are usable in the Czech Republic, some of them are not.

The problematic indicator is that of households owning the car (mobility indicator) necessary for the construction of Towsend's index, and the indicator of long-term ill used in SFVI index itself. While car indicator could be removed, illness indicator is essential for vulnerability evaluation.

Theoretically, we could replace it by other indicator based on different indicators (education level or severity of work, living place and lifespan). The usage of such data would be problematic and would require new study with results very hard to verify and especially compare to original indicator.

Regardless to the above mentioned problems, the search for indicators describing vulnerability is a way to follow, to develop the capability to evaluate the territory as a whole from different (safety oriented) points of view. It does not have to be the evaluation of flood impacts, other natural disasters or even large scale industrial accidents can be taken into account.

\section{Acknowledgements}

A part of this work was written in the framework of dealing with the grant project of Technology Agency of the Czech Republic under number TA01021374 titled "New Technologies for Environmental Protection against the Negative Consequences of Natural Mass Movement”. 


\section{References}

ČSÚ (2003). Sčitání lidu, domu a bytů k 1.3.2001: Obyvatelstvo, byty, domy a domácnosti - Olomouc. Praha: ČSU, 2003. $289 \mathrm{~s}$.

ČSÚ (2011a). Sčitání lidu [online]. Český statistický úřad [cit. 2011-05-26]. Dostupný z: http://www.czso.cz/csu/ redakce.nsf $/$ i/prehled_clanku_unor_2011.

ČSÚ (2011b). Metodika a organizace sčitání lidu [online]. Český statistický úřad [cit. 2011-05-26]. Dostupný z: $\mathrm{http} / / /$ notes3.czso.cz/sldb/sldb.nsf/i/metodika_a_organizace_scitani_lidu.

CDU (2011). Census Dissemination Unit [online]. Census Dissemination Unit [cit. 2011-05-11]. Dostupný z: http://cdu.mimas.ac.uk/.

DE BRUIJN, Karin (2005). Marianne. Resilience and Flood Risk Management - a System Approach Applied to Lowland Rivers. Delft, Nizozemí: DUP Science, 2005. 220 s. ISBN 90-407-2599-3.

DEFRA (2004). The Appraisal of Human related Intangible Impacts of Flooding - $R \&$ \& Technical Report FD2005/TR. Londýn, Velká Británie: DEFRA, 2004. 352 s.

ESRC Census Programme (2011). Census questions, forms and definitions [online]. Census [cit. 2011-05-27]. Dostupný z: https://www.census.ac.uk/guides/Qf.aspx.

JAKUBICKA, Thomas et al. (2011). Health impacts of floods in Europe - Data gaps and information needs from a spatial perspective. Heidelberg, Německo: Universitätsklinikum Heidelberg, 2011. 43 p.

LMC (2010). Absolventi VŠ a Š́ na trhu práce 2010. Praha: LMC, 2010. $12 \mathrm{s.}$

MILOJEVIC, Ai et al. (2011). Long-term effects of flooding on mortality in England and Wales, 1994-2005: controlled interrupted time-series analysis. Environmental Health. 2011, Vol. 10, No. 1, pp. paper 11.

MPSV (2011). Žádost o zařazení do evidence zájemců o zaměstnání [online]. Ministerstvo práce a sociálních věci [cit. 2011-05-26]. Dostupný z: https://formulare.mpsv.cz/okprace/cs/form/edit. jsp?CMD=EditForm\&FN=ZaEZZ100101803\&SSID=lgQ_47XJAv $\sim$ WamoOocPqvioJBWe1oB3Y.

ŘEHÁK, David (2010). Preventivní ochrana obyvatelstva, technické infrastruktury a životního prostředí před negativními vlivy územního rozvoje. SPEKTRUM. 2010, roč. 10, č. 2, s. 41-44.

TAPSELL, S.M. et al. (2002). Vulnerability to flooding: health and social dimensions. Philosophical Transaction of the Royal Society A. 2002, roč. 360, č. 1796, s. 1511-1525.

UNUCKA, Jan et al. (2010). Návrh prototypu komplexního systému včasného varování před povodněmi z přivalových srážek. SPEKTRUM. 2010, roč. 10, č. 2, s. 45-50.

UZIS (2010). Zdravotnická ročenka Moravskoslezského kraje 2009. Praha: UZIS, 2010. 175 s. ISBN 978-807280-898-4.

VOJTĚCH, Jiří et al. (2003). Uplatnění absolventů škol na trhu práce - 2003. Praha: Národní ústav odborného vzdělávání, 2003. 71 s. ISBN 80-85118-80-7. 